OPEN ACCESS

Edited by:

Junfang Wu,

University of Maryland School of Medicine, United States

Reviewed by:

Fengquan Zhou,

Johns Hopkins University,

United States

Yang $\mathrm{Hu}$,

Stanford University, United States

*Correspondence: Larry Benowitz larry.benowitz@childrens.harvard.edu

Specialty section:

This article was submitted to Cellular Neuropathology, a section of the journal

Frontiers in Cellular Neuroscience

Received: 11 February 2021

Accepted: 19 March 2021

Published: 16 April 2021

Citation:

Sergeeva EG, Rosenberg PA and

Benowitz LI (2021)

Non-Cell-Autonomous Regulation of Optic Nerve Regeneration by

Amacrine Cells.

Front. Cell. Neurosci. 15:666798

doi: 10.3389/fncel.2021.666798

\section{Non-Cell-Autonomous Regulation of Optic Nerve Regeneration by Amacrine Cells}

\author{
Elena G. Sergeeva ${ }^{1,2,3}$, Paul A. Rosenberg ${ }^{1,2,3}$ and Larry I. Benowitz ${ }^{2,4,5,6,7 *}$ \\ ${ }^{1}$ Department of Neurology, Boston Children's Hospital, Boston, MA, United States, ${ }^{2}$ Kirby Center for Neuroscience, Boston \\ Children's Hospital, Boston, MA, United States, ${ }^{3}$ Department of Neurology, Harvard Medical School, Boston, MA, \\ United States, ${ }^{4}$ Laboratories for Neuroscience Research in Neurosurgery, Boston Children's Hospital, Boston, MA, \\ United States, ${ }^{5}$ Department of Neurosurgery, Boston Children's Hospital, Boston, MA, United States, ${ }^{6}$ Department \\ of Neurosurgery, Harvard Medical School, Boston, MA, United States, ${ }^{7}$ Department of Ophthalmology, Harvard Medical \\ School, Boston, MA, United States
}

Visual information is conveyed from the eye to the brain through the axons of retinal ganglion cells (RGCs) that course through the optic nerve and synapse onto neurons in multiple subcortical visual relay areas. RGCs cannot regenerate their axons once they are damaged, similar to most mature neurons in the central nervous system (CNS), and soon undergo cell death. These phenomena of neurodegeneration and regenerative failure are widely viewed as being determined by cell-intrinsic mechanisms within RGCs or to be influenced by the extracellular environment, including glial or inflammatory cells. However, a new concept is emerging that the death or survival of RGCs and their ability to regenerate axons are also influenced by the complex circuitry of the retina and that the activation of a multicellular signaling cascade involving changes in inhibitory interneurons - the amacrine cells (AC) - contributes to the fate of RGCs. Here, we review our current understanding of the role that interneurons play in cell survival and axon regeneration after optic nerve injury.

Keywords: axon regeneration, non-cell-autonomous, optic nerve, amacrine cells, retinal ganglion cells

\section{INTRODUCTION: FACTORS DETERMINING RETINAL GANGLION CELL SURVIVAL AND AXON REGENERATION}

A major question in neuroscience is why some neurons in the mature CNS die soon after axonal injury and why almost no neurons are able to regenerate their axons within the CNS even if the cells survive. In a widely studied model of CNS injury and cell death, optic nerve crush (ONC) results in a rapid, transient $\mathrm{Ca}^{2+}$ influx into damaged axons from the extracellular space (Knoferle et al., 2010; Vargas et al., 2015; Ribas et al., 2017), followed by early cytoskeletal disruption (Zhai et al., 2003; Beirowski et al., 2010) and autophagy-mediated disintegration of the axons (Komatsu et al., 2007; Beirowski et al., 2010; Knoferle et al., 2010), which results in continuous degeneration of axons distal to the injury site (McKeon et al., 1995; Beirowski et al., 2010; Knoferle et al., 2010; Anderson et al., 2016). $\mathrm{Ca}^{2+}$ influx along with injury signals propagating retrogradely from the axonal stump activate a MAP kinase signaling cascade involving dual-leucine kinase (DLK), leucinezipper kinase (LZK), and their downstream effectors that culminates in RGC death (Kikuchi et al., 2000; Knoferle et al., 2010; Fernandes et al., 2012; Katome et al., 2013; Watkins et al., 2013; 
Welsbie et al., 2013; Vargas et al., 2015; Yang et al., 2015; Ribas et al., 2017); at the same time, activation of SARM1 culminates in axon degeneration (Gerdts et al., 2016). Certain types of RGCs, specifically intrinsically photosensitive RGCs and alpha-RGCs, are relatively resilient, although in the absence of treatment, most RGCs will eventually die (Park et al., 2008; Duan et al., 2015; Norsworthy et al., 2017; Tran et al., 2019).

While strategies to counteract the pathways leading to cell death can improve RGC survival, the effects are often transitory, or allow long-term survival in a compromised state, or even suppress regeneration (Janssen et al., 2013; Katome et al., 2013; Watkins et al., 2013; Welsbie et al., 2013; Ribas et al., 2017). For example, RGC death following ONC can be suppressed by deletion of the pro-apoptotic regulator bcl2-associated $\mathrm{X}$ protein BAX, but this does not improve axon regeneration (Donahue et al., 2020). Inhibition of DLK and LZK has a robust effect on RGC survival but drastically suppresses RGC axon regeneration (Watkins et al., 2013). Deletion of phosphatase and tensin homologue (PTEN) or upregulation of another mTOR enhancer, osteopontin, induces high but transient protection of RGCs and axon regeneration, and most RGCs go on to die after several weeks (Park et al., 2008; Duan et al., 2015; Li et al., 2017a). Although axon regrowth after injury obviously depends on cell survival, the two processes are distinct, and surviving RGCs do not regenerate axons by default (Chierzi et al., 1999; Goldberg and Barres, 2000; Goldberg et al., 2002a). However, in an exciting recent discovery, Patel et al. showed that inhibition of germinal cell kinase IV (GCK-IV) promotes RGC survival without suppressing axon regeneration (Patel et al., 2020).

The low intrinsic capacity of mature neurons to regenerate axons within the CNS is caused in part by developmentally regulated expression of factors that prevent excessive cell growth and sprouting (He and Jin, 2016; Benowitz et al., 2017; Yin et al., 2019). Manipulation of intrinsic growth pathways, such as activating the PI3K/Akt/mTOR pathway by deleting its endogenous repressor PTEN and others induces significant axonal regeneration in injured RGCs ( $\mathrm{He}$ and Jin, 2016; Benowitz et al., 2017; Yin et al., 2019), as does manipulating developmentally regulated transcription factors that suppress neurons' growth program (Moore et al., 2009, 2011; Apara et al., 2017; Norsworthy et al., 2017; Galvao et al., 2018; Cheng et al., 2020).

At the same time, many studies demonstrate the importance of the environment surrounding injured axons in suppressing or promoting regeneration. Modulation of extrinsic suppressors of growth such as myelin-associated inhibitors, components of extracellular matrix, microglia, or attenuation of pericyte-derived fibrosis, leads to modest improvements of axon regeneration (Benowitz et al., 2017; Yin et al., 2019). On the other hand, some extrinsic factors can promote regeneration. The latter include resident glia and inflammatory cells, macrophages and neutrophils, that can produce a variety of growth factors and chemokines that promote regeneration and RGC survival, including oncomodulin, SDF-1, and, in response to CNTF gene therapy, CCL5 (Benowitz et al., 2017; Yin et al., 2019; Xie et al., 2021). Combinatorial treatment strategies that overcome cell-extrinsic or cell-intrinsic suppressors of growth while simultaneously activating neurons' intrinsic growth state result in impressive levels of regeneration (Fischer et al., 2004a,b; Kurimoto et al., 2010; Sun et al., 2011; de Lima et al., 2012; Dickendesher et al., 2012; Wang et al., 2012; Zhang et al., 2019). Other important factors present in the environment of RGCs derive from other neurons and glia, and include (1) the navigational cues provided by cells along the trajectory of developing axons and in visual target areas (e.g., netrins, semaphorins, Ephrins, Wnts, Slits) (Pfeiffenberger et al., 2005; Feldheim and O'Leary, 2010; Varadarajan and Huberman, 2018); (2) cues from neighbor cells that change RGCs' program of gene expression (Livesey and Cepko, 2001; Goldberg et al., 2002b); (3) regeneration of RGC axons through a peripheral nerve graft (So and Aguayo, 1985; Vidal-Sanz et al., 1987; Aguayo et al., 1991). However, the significance of retinal interneurons and retinal circuitry after RGC axonal injury has received relatively little attention.

A factor that is now coming to light is the instructive role that amacrine cells (AC), the inhibitory interneurons of the retina, play in regulating RGC survival and axon regeneration. ACs either form direct, mostly (but not exclusively) inhibitory synapses (or gap junctions) onto RGC or modulate excitatory inputs from bipolar cells (BC) and inhibitory inputs from other ACs (Kolb and Famiglietti, 1974; Kim et al., 2015). Growing evidence indicates that signaling in this complex circuitry changes upon injury to RGC axons and, in turn, influences RGCs' ability to survive and regrow their axons. In this review we focus on the emerging role of retinal circuitry, and amacrine cells in particular, in RGC survival and axon regeneration after optic nerve injury.

\section{AMACRINE CELL ACTIVITY AND RGC GROWTH STATE}

The earliest evidence of a circuit-level influence on RGC axon outgrowth came from studies carried out in primary retinal cell cultures. Purified neonatal rat RGCs show an irreversible reduction in axon outgrowth when co-cultured with purified ACs but not when co-cultured with BCs (Goldberg et al., 2002b), suggesting that signals from ACs instruct RGCs to decrease their intrinsic growth ability. This effect was seen using isolated AC membranes, pointing to a contact-mediated suppression of RGCs' growth capacity (Goldberg et al., 2002b; Goldberg, 2004). The loss of RGCs' ability to elongate axons coincides temporally with a period of enhanced dendritic growth, suggesting that RGCs can be either in a primarily axonal or dendritic growth state, and that their intrinsic growth state is switched developmentally by a signal arising from ACs (Goldberg et al., 2002b; Goldberg, 2004). In vivo, the decline in RGCs' growth state is associated with numerous changes in these cells' program of gene expression, including an upregulation of the growth suppressive Kruppel-like transcription factors Klf-4 and Klf9, and down-regulation of the growth-promoting transcription factors Klf-6 and Klf-7 (Moore et al., 2009, 2011; Apara and Goldberg, 2014). The developmentally regulated suppressor of axonal growth, PTEN, also shows increased expression during 
this transition (Sakagami et al., 2012). In turn, mTOR decreases in expression during development and is downregulated even more after axonal injury, thereby diminishing RGCs' regenerative capacity (Park et al., 2008; Belin et al., 2015). The JAK2/STAT3 pathway can promote regeneration when activated by certain cytokines, e.g., CNTF, LIF, or IL6, although in the adult CNS, this signaling is negatively regulated by SOCS3 (Smith et al., 2009). In mature mice, recombinant CNTF has little effect on RGCs whereas CNTF gene therapy promotes considerable optic nerve regeneration through an indirect mechanism that involves activation of innate immune cells and glia and expression of chemokine CCL5 (Xie et al., 2021). Other developmentally and injury-regulated intrinsic factors continue to be discovered ( $\mathrm{He}$ and Jin, 2016), although a direct link between these changes and RGC-amacrine cell contact has not yet been investigated.

The growth state of RGCs can be altered by their level of physiological activity, and ACs play an important role in this regard (Goldberg et al., 2002a; Goldberg, 2012; Li et al., 2016; Zhang et al., 2019). In culture, a weak, physiological level of current applied to purified rat primary RGCs, or membrane depolarization by elevated extracellular potassium, improves BDNF-induced axon outgrowth (Goldberg et al., 2002b). In vivo, diminished physiological activity in RGCs diminishes these cells' capacity to regenerate axons and this decline can be partially reversed by expressing melanopsin in RGCs and exposing to light (inducing activation of cell-intrinsic growth pathway mTOR) (Li et al., 2016), by expressing a depolarizing receptor and applying its ligand, or by increasing RGC neural activity with patterned visual stimulation ( $\mathrm{Lim}$ et al., 2016).

RGC activity is reduced by the hyperpolarizing inhibitory drive from ACs, suggesting that such inhibition could suppress regeneration in vivo; and conversely, activation of RGCs by bipolar cells or via silencing of ACs could be permissive for regeneration. More generally, circuit-level activity levels of the retina can alter the activity state of RGCs and thus influence axon regeneration in the optic nerve. Zhang et al. (2019) showed that optic nerve injury increases the activity of ACs (Zhang et al., 2019), which in turn puts a brake on regeneration by inhibiting RGC activity and reducing these cells' responsiveness to growth factors (Zhang et al., 2019) (Figure 1). When hyperactive ACs were silenced, as confirmed by diminished levels of the immediate-early gene c-fos in these cells, RGCs showed increased physiological activity and improved responsiveness to insulinlike growth factor IGF1 (Zhang et al., 2019). This improved responsiveness was mediated by increased expression of the IGF1 receptor on RGCs' primary cilia, which serve as the growth factorsensing antennae of these cells (Guemez-Gamboa et al., 2014), leading to increased RGC survival and axon regeneration. In this study, AC activity was suppressed by either overexpressing the potassium channel Kir2.1 or by overexpressing an RNAbinding insulin-sensitizing protein Lin28 specifically in ACs and horizontal cells. Importantly, whereas IGF1 overexpression or blocking inhibition by either silencing ACs or suppressing neurotransmission with a cocktail of GABA and glycine receptor antagonists induced a moderate level of regeneration by itself, the combination of AC silencing plus IGF1 overexpression had a strongly synergistic effect via increased RGC activity and IGF1 signaling competence (Zhang et al., 2019). Interestingly, Lin28 overexpression in both RGCs and ACs or only in RGCs induced comparable levels of RGC axon regeneration suggesting that Lin28 also has cell-autonomous effects (Wang et al., 2018; Zhang et al., 2019). Further work will be required to understand how Lin28 expression in ACs is linked to AC activity and how axonal injury in RGCs leads to changes in presynaptic retinal circuitry and AC hyperactivation.

Although RGCs can respond to some growth factors without elevating their physiological activity, such as SDF-1 (Yin et al., 2018) and CCL5 (Xie et al., 2021), their ability to respond to the growth factors BDNF and IGF1 is dependent upon enhanced physiological activity (Goldberg et al., 2002a; Duan et al., 2015; Zhang et al., 2019). Activation of RGCs leads to their depolarization and $\mathrm{Ca}^{2+}$ influx which elevates intracellular cAMP levels (Meyer-Franke et al., 1998) and mediates enhanced mTOR signaling and phosphorylation of its downstream effector S6 kinase (Park et al., 2008; Duan et al., 2015; Zhang et al., 2019). $\mathrm{Ca}^{2+}$ influx upon depolarization of RGCs can also trigger rapid post-translational modifications, e.g. phosphorylation of pre-existing transcription factors such as CREB, SRF/FLK, and MEF2, which in turn drive activitydependent transcription of immediate-early genes followed by late response genes (Yap and Greenberg, 2018). The activityregulated genes control the expression of numerous effectors of cell survival and regeneration, including growth factors and receptors to growth factors (Yap and Greenberg, 2018). Conversely, excessive inhibition of RGCs by hyperactive ACs would be expected to result in reduced $\mathrm{Ca}^{2+}$ influx into RGCs, diminished $\mathrm{Ca}^{2+}$-mediated, activity-dependent transcription, and suppression of RGCs' intrinsic growth state. However, despite the increased inhibitory drive onto RGCs due to elevated amacrine cell activity after optic nerve damage, elevation of RGCs' intrinsic growth state (PTEN deletion, SOCS3 deletion combined with CNTF, manipulation of transcription factors) can nevertheless increase axon regeneration, as we discussed above.

\section{AMACRINE CELLS AND ZINC SIGNALING IN THE RETINA}

In addition to diminishing RGCs' activity state, do ACs produce other signals that suppress RGC survival and regenerative ability? Our lab recently reported that one such signal may be mobile zinc $\left(\mathrm{Zn}^{2+}\right)$ (Li et al., 2017a; Trakhtenberg et al., 2018). Elevation of mobile $\mathrm{Zn}^{2+}$ in $\mathrm{AC}$ terminals within the inner plexiform layer (IPL) of the retina, as demonstrated by selenite autometallography (AMG), is one of the earliest changes seen in mouse retina after optic nerve injury ( $\mathrm{Li}$ et al., 2017a) (Figure 2).

Normally, zinc is covalently bound to proteins, including many transcription factors and enzymes, enabling their folding and thus their functionality (McCall et al., 2000; Kochanczyk et al., 2015). Some neurons, including particular cells in the hippocampus, cerebral cortex, and spinal cord, sequester $\mathrm{Zn}^{2+}$ in synaptic vesicles and co-release it with classical neurotransmitters (Nakashima and Dyck, 2009; Sensi et al., 2009, 2011; Pan et al., 2011; Kimura and Kambe, 2016). Intracellular levels of 

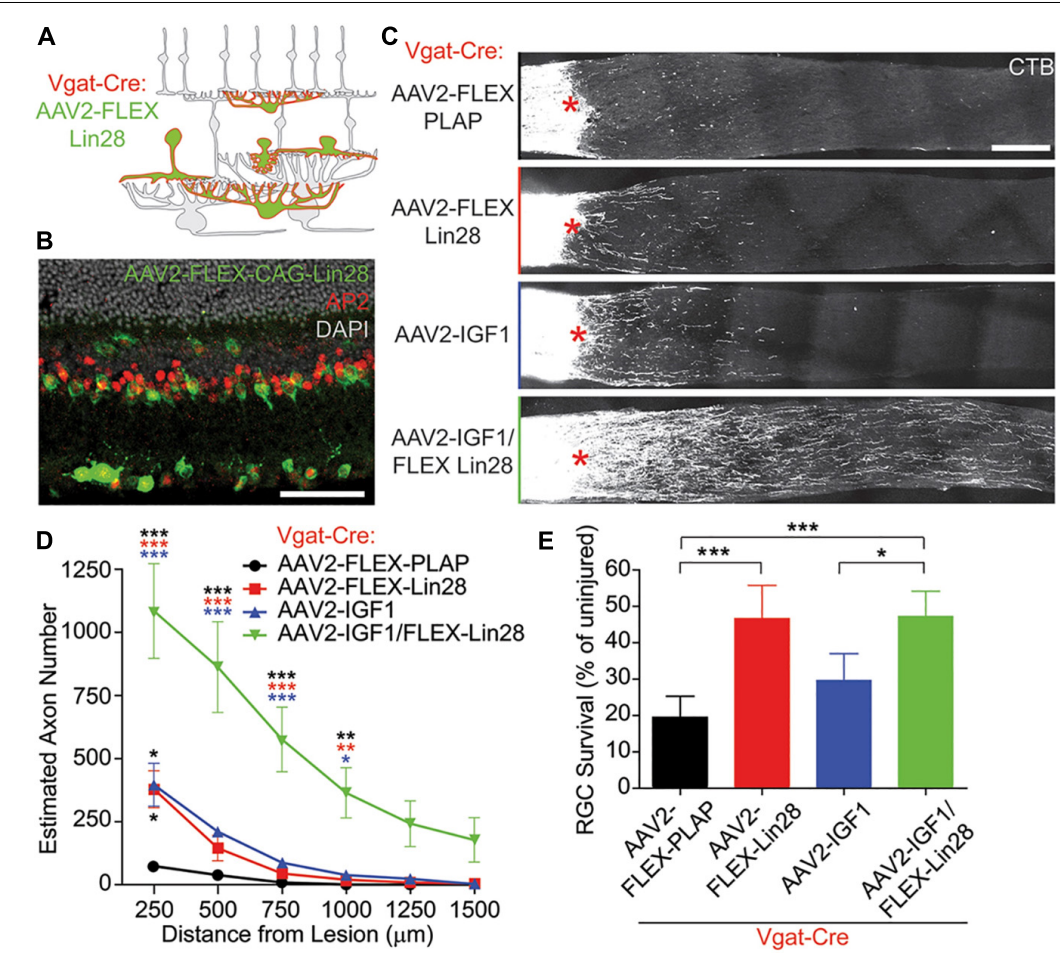

FIGURE 1 | Lin28 expression in inhibitory neurons promotes RGC survival and IGF1-induced axonal regeneration. (A,B) Schematic (A) and example (B) confocal image stack showing expression of AAV2-FLEX-Lin28 in the intact Vgat-Cre transgenic retina where Lin28 expression is restricted to amacrine and horizontal cells. (C) Representative confocal image stacks of CTB labeled RGC axons 2 weeks after optic nerve crush with amacrine cell restricted expression of Lin28. Asterisks indicate crush site. (D) Quantification of the extent of RGC axon regeneration in treatment groups restricted to amacrine cells. Asterisk colors indicate the group that the $p$ value was significant against. (E) Quantification of RGC survival relative to RGC density observed in intact retinas in treatment groups restricted to amacrine cells. $n=5$ mice per group. Scale bar, $50 \mu \mathrm{m}$ in (B), and $200 \mu \mathrm{m}$ in (C). ${ }^{*}$, ${ }^{\star \star},{ }^{\star \star *} p<0.05,0.01,0.001$, respectively. Reprinted from Zhang et al. (2019) with permission.

mobile $\mathrm{Zn}^{2+}$ can vary depending on many factors, including oxidative stress and liberation of $\mathrm{Zn}^{2+}$ from oxidized proteins (Aravindakumar et al., 1999; Sensi et al., 1999; Spahl et al., 2003; Aras and Aizenman, 2011), redistribution of $\mathrm{Zn}^{2+}$ between intracellular pools (Sekler et al., 2007; Maret, 2017; Ji et al., 2020), and transcriptional and posttranscriptional regulation of $\mathrm{Zn}^{2+}$-regulating proteins (Saydam et al., 2002; Jackson et al., 2008). It is important to maintain $\mathrm{Zn}^{2+}$ concentrations within a narrow range in different intracellular compartments to maintain proper $\mathrm{Zn}^{2+}$ availability to numerous $\mathrm{Zn}^{2+}$-binding proteins while at the same time preventing mismetallation and $\mathrm{Zn}^{2+}$ toxicity (Aras and Aizenman, 2011). For this purpose, a complex homeostatic machinery comprised of metal buffering proteins - metallothioneins and zinc transporters (ZnTs and ZIPs) has evolved (Hidalgo et al., 2001; Cousins et al., 2006; McAllister and Dyck, 2017).

Metallothioneins, glutathione and other metal-containing peptides and proteins can liberate $\mathrm{Zn}^{2+}$ and copper ions $\left(\mathrm{Cu}^{+}\right.$ or $\mathrm{Cu}^{2+}$ ) when subjected to oxidative stress (Maret, 1995). For example, reactive oxygen species and peroxynitrite can oxidize residues on the metal-binding sites of metal-binding proteins and release the cations (Sensi et al., 1999; Hidalgo et al., 2001; Spahl et al., 2003; Zhang et al., 2004; Aras and Aizenman, 2011). $\mathrm{Cu}^{+}$ and $\mathrm{Cu}^{2+}$, as redox-active ions, can directly displace $\mathrm{Zn}^{2+}$ from metallothioneins or engage in oxidative reactions, ultimately leading to more $\mathrm{Zn}^{2+}$ release (Krężel and Maret, 2017). The apparent elevation of mobile $\mathrm{Zn}^{2+}$ in AC terminals that synapse onto RGCs that occurs soon after optic nerve injury points to AC and $\mathrm{Zn}^{2+}$ dysregulation as a potential major factor of abnormal retinal circuit homeostasis after injury (Li et al., 2017a) (Figure 2).

\section{Role of Nitric Oxide and Presumptive Role of Glutamate and Bipolar Cells in Retinal $\mathrm{Zn}^{2+}$ Homeostasis}

Little is known about the mechanisms underlying the increase in AMG signal in the retina following the injury of RGC axons. A preliminary report used a novel fluorescent nitric oxide (NO) sensor, $\mathrm{Cu}_{2}$ FL2E (Pluth et al., 2011), to provide evidence that the production of $\mathrm{NO}$ is rapidly and persistently upregulated in the retina after optic nerve injury, and that NO generation is upstream of the accumulation of AMG signal in the retinal IPL ( $\mathrm{Li}$ et al., 2017b). One possibility is that reactive nitrogen species produced after injury, e.g., peroxynitrite, can liberate $\mathrm{Zn}^{2+}$ from metallothioneins (Zhang et al., 2004; Nakamura et al., 2015; Wolhuter et al., 2018). Alternatively, NO can contribute to an increase of intracellular $\mathrm{Zn}^{2+}$ via a cGMP/PKG-dependent release of $\mathrm{Zn}^{2+}$ from internal stores (Jang et al., 2007). 

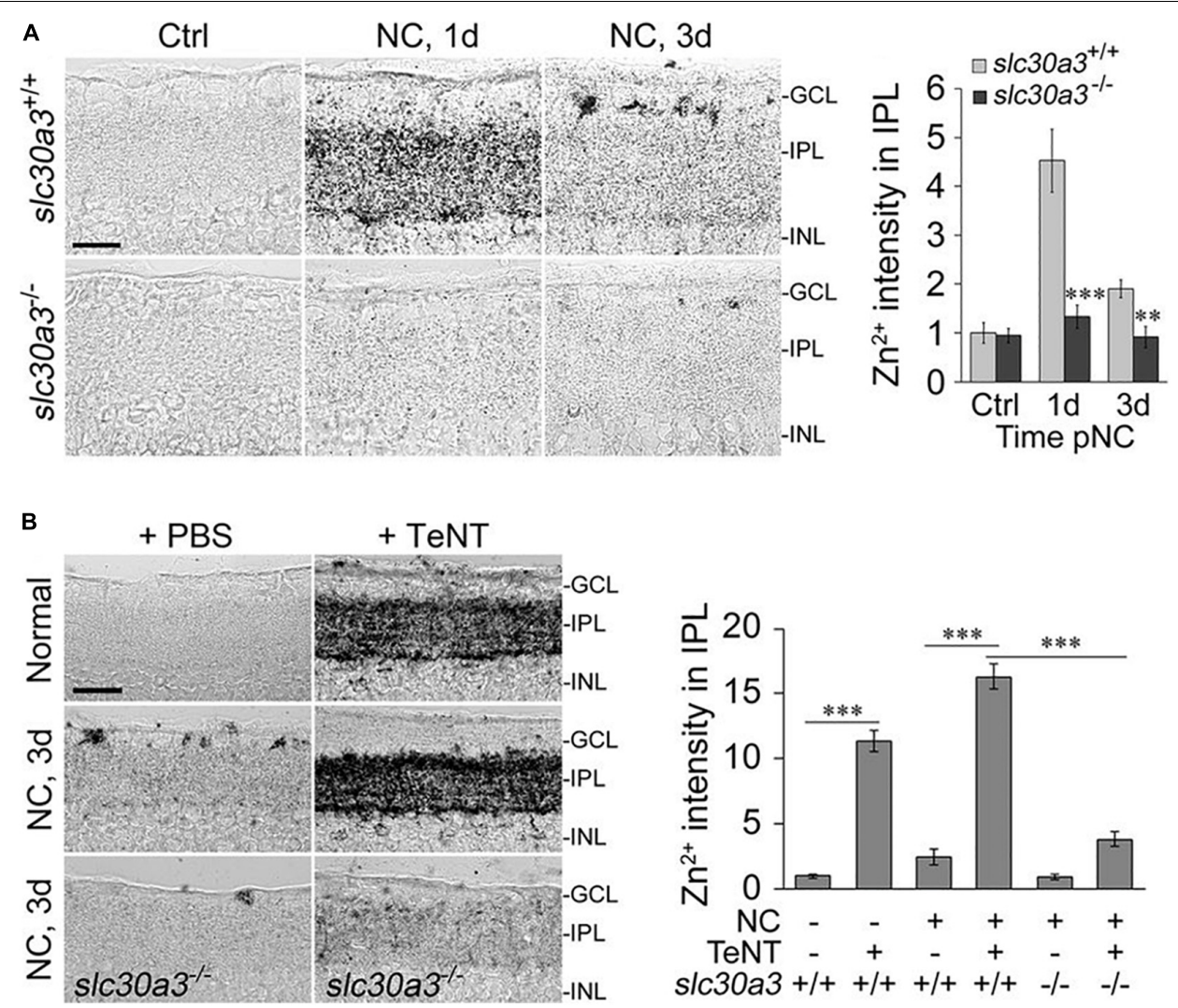

FIGURE $2 \mid \mathrm{Zn}^{2+}$ accumulation in the retina and its role in axon regeneration after optic nerve crush (NC). (A) Zinc accumulates in the inner plexiform layer (IPL) of the retina shortly after $\mathrm{NC}$ in wild-type mice $\left(\mathrm{slc} 30 \mathrm{a} 3^{+/+}\right)$but not in mice lacking the zinc transporter $\mathrm{ZnT3}\left(\mathrm{slc} 30 \mathrm{a} 3^{-/}\right)$: images and quantitation of AMG staining in the IPL ( $n=6$ retinas per group) of wild-type and slc30a3-/ littermates. Note elevation of AMG signal on day 1 following NC in wild-type mice and decline to near normal level by day 3 (Scale bar, $25 \mu \mathrm{m} ;{ }^{* *} P<0.01,{ }^{* * *} P<0.001$ ). (B) Tetanus toxin (TeNT) blocks vesicular release of $\mathrm{Zn}^{2+}$, causing continued $\mathrm{Zn}{ }^{2+}$ build-up in the IPL: images and quantification of AMG staining in the IPL after NC with and without intraocular injection of TeNT (20 nM). Note elevation of AMG staining in the IPL of normal, uninjured mice and in wild-type mice, at 3 days after NC, a time point at which AMG staining in the IPL would normally dissipate. Deletion of the gene encoding ZnT3 eliminates $\mathrm{Zn}^{2+}$ accumulation in the IPL (Scale bar, $50 \mu \mathrm{m}$; *** $<0.001$ ). Adapted from Li et al. (2017a) with permission.

NO is synthetized by nitric oxide synthetase, one isoform of which, NOS1, is expressed exclusively in a subset of ACs (Yamamoto et al., 1993; Oh et al., 1998). Production of NO in ACs after optic nerve injury points to the existence of an as yet unidentified retrograde signal linking RGC axon injury and NOS1 activation. NOS1 activation can be triggered by $\mathrm{Ca}^{2+}$ entering ACs upon activation of voltage-gated calcium channels or through NMDA or AMPA receptors (Christopherson et al., 1999). These latter receptors can be activated by glutamate that is either synaptically released by BCs or elevated due to a reversal of glutamate transporters, e.g., GLT-1, EAAC1, GLAST, that are expressed on retinal neurons or glia, including astrocytes and Mueller cells. Glutamate transporters normally take up extracellular glutamate but can reverse the direction of transport and release glutamate upon changes in $\mathrm{Na}^{+}$and $\mathrm{K}^{+}$gradients or membrane potential (Szatkowski et al., 1990; Danbolt, 2001; Grewer et al., 2008; Armbruster et al., 2016; Rimmele et al., 2017). Our preliminary studies show that BC-specific knockout of GLT-1 may prevent mobile $\mathrm{Zn}^{2+}$ accumulation in AC terminals after ONC, as does inhibition of NMDA receptors (Hanovice et al., 2019). Taken together, these results suggest that reversal of the glutamate transporter GLT-1 in BCs, activation of NMDA receptors, and NO elevation may act upstream of $\mathrm{Zn}^{2+}$ liberation and accumulation in AC terminals after optic nerve injury (Hanovice et al., 2019).

\section{Effect of Presynaptic Zinc on Retinal Ganglion Cells}

In line with previous studies showing that $\mathrm{Zn}^{2+}$ levels in the brain (visualized by AMG) are abolished in mice lacking the zinc transporter protein $\mathrm{ZnT} 3$, the accumulation of $\mathrm{Zn}^{2+}$ in $\mathrm{AC}$ terminals following ONC is similarly absent in $\mathrm{ZnT} 3$ knock-out mice (Li et al., 2017a) (Figure 2A). Because ZnT3 enables $\mathrm{Zn}^{2+}$ to be sequestered in synaptic vesicles (Palmiter et al., 1996), this finding implies that the $\mathrm{Zn}^{2+}$ that is mobilized in ACs after ONC is stored in synaptic vesicles (Palmiter et al., 1996; Li et al., 2017a). In conformity with this idea, the $\mathrm{Zn}^{2+}$ that accumulates in the retinal IPL after ONC normally dissipates by 48 hour after ONC (Li et al., 2017a) but continues to accumulate if exocytosis is inhibited using Clostridium tetani neurotoxin (TeNT) (Li et al., 2017a; Sergeeva et al., 2019) (Figure 2B). Blockade of synaptic 
release from AC terminals with TeNT promotes RGC survival and optic nerve regeneration (Li et al., 2017a; Sergeeva et al., 2019). These data suggest that $\mathrm{Zn}^{2+}$ packaged into synaptic vesicles and released from AC terminals, or the neurotransmitter used by these neurons, or both, may negatively affect RGC survival and block axon regeneration.

It should be noted, however, that because the chelators used in the aforementioned studies are not entirely specific to $\mathrm{Zn}^{2+}$, it remains possible that other cations, e.g., $\mathrm{Cu}^{+}$or $\mathrm{Cu}^{2+}$, could also be involved. Copper is stored in synaptic vesicles and released upon depolarization (Kardos et al., 1989). Moreover, the method used to detect $\mathrm{Zn}^{2+}$, e.g., AMG, although generally regarded as being specific to $\mathrm{Zn}^{2+}$ (Danscher and Stoltenberg, 2005), may also provide ambiguous results, as selenite may potentially form complexes with other divalent cations, suggesting that vesicular $\mathrm{Cu}^{+} / \mathrm{Cu}^{2+}$ may potentially contribute to AMG staining. On the other hand, the observation that the AMG signal in the retinal IPL is abolished in mice lacking ZnT3 supports the hypothesis that the AMG signal reflects $\mathrm{Zn}^{2+}$ per se, provided that $\mathrm{ZnT} 3$ does not transport other divalent cations, such as copper. At this stage, we also do not know whether other metals act downstream or upstream of $\mathrm{Zn}^{2+}$ release and accumulation.

Synaptic release of $\mathrm{Zn}^{2+}$ from ACs could affect RGC signaling via numerous pathways. Synaptic $\mathrm{Zn}^{2+}$ can modulate the activity of NMDA, GABA and glycine receptors, thereby modulating cell excitation and inhibition (Suwa et al., 2001; Kaneda et al., 2005; Sensi et al., 2011; Vergnano et al., 2014). $\mathrm{Zn}^{2+}$ modulates glycine receptors in a biphasic manner, potentiating inhibition at low micromolar concentrations while suppressing glycinergic currents at high concentrations (Kaneda et al., 2005). Potentiation of glycine receptors on RGCs would be expected to decrease RGC activity which, as noted above, would diminish RGC survival and axon regeneration (Goldberg et al., 2002a; Goldberg, 2012; Zhang et al., 2019). In addition, $\mathrm{Zn}^{2+}$ interacting with the $\mathrm{Zn}^{2+}$-sensing receptor $\mathrm{ZnR} / \mathrm{GPR} 39$ could regulate the transport of $\mathrm{Na}^{+}, \mathrm{K}^{+}, \mathrm{Cl}^{-}$(Chorin et al., 2011; Saadi et al., 2012) and trigger $\mathrm{G} \alpha_{q}$-dependent signaling and subsequent release of $\mathrm{Ca}^{2+}$ from endoplasmic reticulum stores, thereby modulating ERK/MAPK and PI3K/Akt/mTOR signaling, both of which are important for cell survival and growth (Azriel-Tamir et al., 2004; Hershfinkel, 2018). Potentially, intracellular $\mathrm{Zn}^{2+}$ elevation can induce cell death by upregulating proapoptotic factors (Jiang et al., 2001; Zhang et al., 2004, 2006, 2007; Cohen et al., 2012), mitochondrial impairment (Sensi et al., 1999; Baud et al., 2004; Ji et al., 2020), synthesis of reactive oxygen species (Wang et al., 2004; Bishop et al., 2007), activation of MAPK/p38 signaling and activation of voltage-gated $\mathrm{K}^{+}$channels, leading to $\mathrm{K}^{+}$efflux (McLaughlin et al., 2001; Bossy-Wetzel et al., 2004; Zhang and Rosenberg, 2004; Zhang et al., 2004, 2006, 2007; McCord and Aizenman, 2013).

Chelation of $\mathrm{Zn}^{2+}$ after ONC can potentially inhibit histone deacetylases (HDACs), enzymes that deacetylate histone proteins, thereby rendering chromatin more accessible for transcription. The deacetylating activity of HDACs depends on the binding of $\mathrm{Zn}^{2+}$ in the HDAC active site pocket (Pelzel et al., 2010; Li et al., 2019). Prevention of histone deacetylation by inhibition of HDAC activity caused by removal of $\mathrm{Zn}^{2+}$ from HDACs can potentially facilitate transcription of activity-dependent genes and ultimately add to the effects of RGC activation. Along these lines, inhibition of HDAC activity alone has been shown to protect RGCs after injury (Gaub et al., 2011; Zhang et al., 2012; Chindasub et al., 2013; Janssen et al., 2013; Schmitt et al., 2014).

An additive effect on RGC survival by metal chelators was observed in combinatorial treatment with deletion of PTEN, producing survival of RGCs that was substantially greater at 12 weeks post ONC compared to PTEN deletion itself (Li et al., 2017a). Knockdown of another intrinsic suppressor of axonal growth, Klf-9, also demonstrated enhanced RGC survival when combined with chelation (Trakhtenberg et al., 2018).

\section{WHY DO AMACRINE CELLS BECOME HYPERACTIVE? A HYPOTHESIS}

It is largely unknown how or why ACs become hyperactive after optic nerve injury (Zhang et al., 2019). Activation of NMDA or AMPA receptors on ACs by glutamate released from BCs leads to $\mathrm{AC}$ depolarization, increased firing, and increased release of glycine and GABA onto RGCs, as well as onto BCs and other ACs (Kolb and Famiglietti, 1974). Activation of GABA or glycine receptors on ACs by GABA or glycine released from other ACs causes these cells to become hyperpolarized to a level closer to the reversal potential for $\mathrm{Cl}^{-}$, which in these cells is normally more negative than the membrane potential, reducing action potential firing, with a net effect of decreasing inhibitory tone projecting onto RGCs. However, under some circumstances, for example, early in development, the reversal potential for chloride may be depolarized with respect to the membrane potential due to the electrochemical gradient driven by high intracellular $\mathrm{Cl}^{-}$. Such switch in GABA function is mediated by changes in expression or localization of $\mathrm{Cl}^{-}$transporters: the neuronspecific $\mathrm{K}^{+}-\mathrm{Cl}^{-}$cotransporter $\mathrm{KCC} 2$ and the $\mathrm{Na}^{+}-\mathrm{K}^{+}-\mathrm{Cl}^{-}$ cotransporter NKCC1 expressed in immature neurons (Kaila et al., 2014). Consequently, the activation state of ACs depends not only on the sum of excitatory and inhibitory inputs onto these cells at any moment, but also on the $\mathrm{Cl}^{-}$gradient that determines the polarity of the GABAergic and glycinergic drive onto these cells. Alteration of the $\mathrm{Cl}^{-}$gradient may be important in retinal network dysfunction and has been investigated in several studies (Hoffpauir et al., 2006; Krishnan and Gleason, 2015).

$\mathrm{Cl}^{-}$gradient alteration induced by decreased KCC2 function or expression is an important cause of disinhibition in cells and circuits, and has been shown to participate in several neurological disorders including epilepsy (Moore et al., 2017; Liu et al., 2019), spasticity after spinal cord injury (Boulenguez et al., 2010; Chen et al., 2018), autism and Rett syndrome (Tang et al., 2016) and chronic pain (Coull et al., 2003; Hasbargen et al., 2010), all of which are characterized by a failure of inhibition and neural hyperactivation (Nabekura et al., 2002; Kaila et al., 2014). KCC2 cotransport utilizes a $\mathrm{K}^{+}$gradient to extrude $\mathrm{Cl}^{-}$(Payne et al., 2003; Kaila et al., 2014), therefore the $\mathrm{Cl}^{-}$transporter activity may decrease with high extracellular $\mathrm{K}^{+}$following ischemia, injury, $\mathrm{Na}^{+} / \mathrm{K}^{+}$ATP dysfunction and reduced production of ATP due to mitochondrial compromise (Kleber, 1984; Hughes and 
Cidlowski, 1999; Kaila et al., 2014; Doyon et al., 2016). KCC2 is highly expressed in the retina (Vardi et al., 2000; Vu et al., 2000). With increased extracellular $\mathrm{K}^{+}$after $\mathrm{K}^{+}$efflux from injured RGCs (Yu et al., 1997; Diem et al., 2001; Zhong et al., 2013) or activated microglia (Fordyce et al., 2005) KCC2-dependent $\mathrm{Cl}^{-}$ extrusion in ACs may be diminished.

KCC2, like many intracellular proteins, can be regulated by phosphorylation, trafficking and proteolytic cleavage (Kaila et al., 2014; Doyon et al., 2016; Kahle and Delpire, 2016). Extracellular modifiers of KCC2 expression and function include $\mathrm{BDNF} / \mathrm{TrkB}$, serotonin/5HT2A, glutamate/NMDA, the $\mathrm{Zn}^{2+}$ sensing receptor GPR39, and noradrenaline signaling (Wake et al., 2007; Hershfinkel et al., 2009; Bos et al., 2013; Watanabe and Fukuda, 2015; Tang et al., 2019). In addition, KCC2 activity can be suppressed by both NO and intracellular zinc (Yassin et al., 2014) shown to be elevated in ACs after injury (Li et al., 2017a,b).

KCC2 independent-, NO-mediated elevation of intracellular $\mathrm{Cl}^{-}$could be another potential mechanism of AC disinhibition after optic nerve injury. In chick ACs in vitro, NO transiently reverses GABA- and glycine-gated currents, converting inhibition of ACs into excitation, thereby increasing the firing of these cells and thus enhanced inhibitory drive on their synaptic partners (e.g., RGCs). This NO-induced shift in $\mathrm{E}_{\mathrm{Cl}-}$ is likely due to release of $\mathrm{Cl}^{-}$from intracellular stores (Hoffpauir et al., 2006; Krishnan and Gleason, 2015; Krishnan et al., 2017; Maddox and Gleason, 2017; Maddox et al., 2018). In addition, NO may drive synaptic glutamate release from BCs without membrane depolarization via a TRPC $\mathrm{Ca}^{2+}$ influx-mediated pathway, as shown in the chick retina (Maddox et al., 2018), further depolarizing ACs.

In summary, dysregulation of $\mathrm{Cl}^{-}$gradients in the inner retina may be a part of the early pathological process following optic nerve or RGC injury. Reciprocally connected ACs and BCs, in the face of $\mathrm{Cl}^{-}$gradient collapse, can form circuits with positive feedback loops that may rapidly lead to hyperactivation of ACs and thus increased inhibition of their synaptic targets (Marc and Liu, 2000; Marc et al., 2014; Doyon et al., 2015, 2016). Whether the complex retinal circuitry is particularly susceptible to persistent disinhibition of ACs after injury remains to be studied.

\section{CONCLUSION: FROM RETINAL GANGLION CELLS TO RETINAL CIRCUITS}

Silencing ACs or introducing chelators into the eye to suppress $\mathrm{Zn}^{2+}$ accumulation in amacrine cell terminals are additive with the effects of manipulating RGC-intrinsic factors (PTEN deletion, Klf-9 suppression, upregulation of osteopontin) on RGC survival and regeneration (Li et al., 2017a; Trakhtenberg et al., 2018; Zhang et al., 2019). These findings suggest that dysfunction of the retinal network, and particularly interneuron (AC) dysfunction, is part of the pathological process following optic nerve injury, and that the capacity of RGCs to survive and regenerate may depend in part on the activity of the other retinal neurons with which they are connected.
Although the non-cell-autonomous regulation of neuronal survival and pathological functioning by other neurons is just starting to be recognized as being important after optic nerve injury, neuronal circuits have been implicated in various pathological processes and cell death in other neurodegenerative diseases (Palop et al., 2006; Simon et al., 2016). In amyotrophic lateral sclerosis, hyperexcitability and death of motoneurons have been attributed to a non-cell autonomous response to a defect in premotor interneurons (Wainger et al., 2014; Held et al., 2019). In Parkinson's disease, alterations of basal ganglia circuitry have been shown to precede loss of substantia nigra neurons (McGregor and Nelson, 2019), as was shown for striatal spiny neurons in Huntington's disease (Creus-Muncunill and Ehrlich, 2019). In Alzheimer's disease, early circuitry dysfunction may be induced by amyloid beta-mediated suppression of glutamate reuptake and a consequent vicious cycle of neuronal hyperactivation and cell death (Zott et al., 2018, 2019). In autism and Alzheimer's disease, dysfunction of interneurons has been implicated (Palop et al., 2006; Palop and Mucke, 2016; MartinezLosa et al., 2018). Disruption of excitatory and inhibitory circuits and excitatory-inhibitory imbalance also seem important in the pathogenesis of Rett syndrome and autism (Nelson and Valakh, 2015; Patrizi et al., 2020). Here we assemble evidence that optic nerve injury induces changes in retinal circuitry that is initiated by an as-yet unidentified signal from injured RGCs to retinal interneurons that alters the function of amacrine cells, in turn influencing the survival and regenerative capacity of injured RGCs.

Despite considerable progress in the areas of RGC protection and optic nerve regeneration, there is still a long way to go before we achieve satisfactory levels of functional recovery. One factor that is now coming to be appreciated is the crosstalk between cell-intrinsic and cell-extrinsic factors, particularly the role of neural circuits and the activity of neurons that form synapses with the affected cells. A greater understanding of the role of circuit activity might substantially augment the outcome achieved by manipulating RGCs' intrinsic growth potential and cell-extrinsic factors.

\section{AUTHOR CONTRIBUTIONS}

All authors conceptualized the study and wrote the manuscript.

\section{FUNDING}

We are grateful for the support of the NIH (NEI R01EY027881 to PR and LB, NEI R01EY024481 to PR and LB, and NINDS IDDRC HD018655), and the Adelson Medical Research Foundation.

\section{ACKNOWLEDGMENTS}

We wish to thank Dr. Xin Tang (Boston Children's Hospital/Harvard Medical School) for critically reading parts of the manuscript. 


\section{REFERENCES}

Aguayo, A. J., Rasminsky, M., Bray, G. M., Carbonetto, S., McKerracher, L., Villegas-Perez, M. P., et al. (1991). Degenerative and regenerative responses of injured neurons in the central nervous system of adult mammals. Philos. Trans. R. Soc. Lond. B Biol. Sci. 331, 337-343. doi: 10.1098/rstb.1991.0025

Anderson, M. A., Burda, J. E., Ren, Y., Ao, Y., O’Shea, T. M., Kawaguchi, R., et al. (2016). Astrocyte scar formation aids central nervous system axon regeneration. Nature 532, 195-200. doi: 10.1038/nature17623

Apara, A., Galvao, J., Wang, Y., Blackmore, M., Trillo, A., Iwao, K., et al. (2017). KLF9 and JNK3 interact to suppress axon regeneration in the adult CNS. J. Neurosci. 37, 9632-9644. doi: 10.1523/jneurosci.0643-16.2017

Apara, A., and Goldberg, J. L. (2014). Molecular mechanisms of the suppression of axon regeneration by KLF transcription factors. Neural Regen. Res. 9, 14181421. doi: 10.4103/1673-5374.139454

Aras, M. A., and Aizenman, E. (2011). Redox regulation of intracellular zinc: molecular signaling in the life and death of neurons. Antioxid. Redox Signal. 15, 2249-2263. doi: 10.1089/ars.2010.3607

Aravindakumar, C. T., Ceulemans, J., and De Ley, M. (1999). Nitric oxide induces $\mathrm{Zn} 2+$ release from metallothionein by destroying zinc-sulphur clusters without concomitant formation of S-nitrosothiol. Biochem. J. 344 (Pt 1), 253-258. doi: 10.1042/0264-6021:3440253

Armbruster, M., Hanson, E., and Dulla, C. G. (2016). Glutamate clearance is locally modulated by presynaptic neuronal activity in the cerebral cortex. J. Neurosci. 36, 10404-10415. doi: 10.1523/jneurosci.2066-16.2016

Azriel-Tamir, H., Sharir, H., Schwartz, B., and Hershfinkel, M. (2004). Extracellular zinc triggers ERK-dependent activation of $\mathrm{Na}+/ \mathrm{H}+$ exchange in colonocytes mediated by the zinc-sensing receptor. J. Biol. Chem. 279, 51804-51816. doi: 10.1074/jbc.M406581200

Baud, O., Li, J., Zhang, Y., Neve, R. L., Volpe, J. J., and Rosenberg, P. A. (2004). Nitric oxide-induced cell death in developing oligodendrocytes is associated with mitochondrial dysfunction and apoptosis-inducing factor translocation. Eur. J. Neurosci. 20, 1713-1726. doi: 10.1111/j.1460-9568.2004. 03616.x

Beirowski, B., Nogradi, A., Babetto, E., Garcia-Alias, G., and Coleman, M. P. (2010). Mechanisms of axonal spheroid formation in central nervous system Wallerian degeneration. J. Neuropathol. Exp. Neurol. 69, 455-472. doi: 10.1097/ NEN.0b013e3181da84db

Belin, S., Nawabi, H., Wang, C., Tang, S., Latremoliere, A., Warren, P., et al. (2015). Injury-induced decline of intrinsic regenerative ability revealed by quantitative proteomics. Neuron 86, 1000-1014. doi: 10.1016/j.neuron.2015. 03.060

Benowitz, L. I., He, Z., and Goldberg, J. L. (2017). Reaching the brain: advances in optic nerve regeneration. Exp. Neurol. 287(Pt 3), 365-373. doi: 10.1016/j. expneurol.2015.12.015

Bishop, G. M., Dringen, R., and Robinson, S. R. (2007). Zinc stimulates the production of toxic reactive oxygen species (ROS) and inhibits glutathione reductase in astrocytes. Free Radic. Biol. Med. 42, 1222-1230. doi: 10.1016/j. freeradbiomed.2007.01.022

Bos, R., Sadlaoud, K., Boulenguez, P., Buttigieg, D., Liabeuf, S., Brocard, C., et al. (2013). Activation of 5-HT2A receptors upregulates the function of the neuronal K-Cl cotransporter KCC2. Proc. Natl. Acad. Sci. U.S.A. 110, 348-353. doi: $10.1073 /$ pnas. 1213680110

Bossy-Wetzel, E., Talantova, M. V., Lee, W. D., Scholzke, M. N., Harrop, A., Mathews, E., et al. (2004). Crosstalk between nitric oxide and zinc pathways to neuronal cell death involving mitochondrial dysfunction and p38-activated K+ channels. Neuron 41, 351-365. doi: 10.1016/s0896-6273(04)00015-7

Boulenguez, P., Liabeuf, S., Bos, R., Bras, H., Jean-Xavier, C., Brocard, C., et al. (2010). Down-regulation of the potassium-chloride cotransporter KCC2 contributes to spasticity after spinal cord injury. Nat. Med. 16, 302-307. doi: 10.1038/nm.2107

Chen, B., Li, Y., Yu, B., Zhang, Z., Brommer, B., Williams, P. R., et al. (2018). Reactivation of dormant relay pathways in injured spinal cord by KCC2 manipulations. Cell 174, 521-535.e13. doi: 10.1016/j.cell.2018.06.005

Cheng, Y., Yin, Y., Zhang, A., Bernstein, A. M., Kawaguchi, R., Gao, K., et al. (2020). Transcription factor network analysis identifies REST/NRSF as an intrinsic regulator of CNS regeneration. BioRxiv [Preprint] 12.13.413104. BioRxiv:12.13.413104
Chierzi, S., Strettoi, E., Cenni, M. C., and Maffei, L. (1999). Optic nerve crush: axonal responses in wild-type and bcl-2 transgenic mice. J. Neurosci. 19, 8367-8376.

Chindasub, P., Lindsey, J. D., Duong-Polk, K., Leung, C. K., and Weinreb, R. N. (2013). Inhibition of histone deacetylases 1 and 3 protects injured retinal ganglion cells. Invest. Ophthalmol. Vis. Sci. 54, 96-102. doi: 10.1167/iovs.1210850

Chorin, E., Vinograd, O., Fleidervish, I., Gilad, D., Herrmann, S., Sekler, I., et al. (2011). Upregulation of KCC2 activity by zinc-mediated neurotransmission via the mZnR/GPR39 receptor. J. Neurosci. 31, 12916-12926. doi: 10.1523/ jneurosci.2205-11.2011

Christopherson, K. S., Hillier, B. J., Lim, W. A., and Bredt, D. S. (1999). PSD-95 assembles a ternary complex with the N-methyl-D-aspartic acid receptor and a bivalent neuronal NO synthase PDZ domain. J. Biol. Chem. 274, 27467-27473. doi: $10.1074 /$ jbc. 274.39 .27467

Cohen, L., Azriel-Tamir, H., Arotsker, N., Sekler, I., and Hershfinkel, M. (2012). Zinc sensing receptor signaling, mediated by GPR39, reduces butyrate-induced cell death in HT29 colonocytes via upregulation of clusterin. PLoS One 7:e35482. doi: 10.1371/journal.pone.0035482

Coull, J. A., Boudreau, D., Bachand, K., Prescott, S. A., Nault, F., Sik, A., et al. (2003). Trans-synaptic shift in anion gradient in spinal lamina I neurons as a mechanism of neuropathic pain. Nature 424, 938-942. doi: 10.1038/ nature 01868

Cousins, R. J., Liuzzi, J. P., and Lichten, L. A. (2006). Mammalian zinc transport, trafficking, and signals. J. Biol. Chem. 281, 24085-24089. doi: 10.1074/jbc. R600011200

Creus-Muncunill, J., and Ehrlich, M. E. (2019). Cell-autonomous and non-cellautonomous pathogenic mechanisms in Huntington's disease: insights from in vitro and in vivo models. Neurotherapeutics 16, 957-978. doi: 10.1007/ s13311-019-00782-9

Danbolt, N. C. (2001). Glutamate uptake. Prog. Neurobiol. 65, 1-105. doi: 10.1016/ s0301-0082(00)00067-8

Danscher, G., and Stoltenberg, M. (2005). Zinc-specific autometallographic in vivo selenium methods: tracing of zinc-enriched (ZEN) terminals, ZEN pathways, and pools of zinc ions in a multitude of other ZEN cells. J. Histochem. Cytochem. 53, 141-153. doi: 10.1369/jhc.4R6460.2005

de Lima, S., Koriyama, Y., Kurimoto, T., Oliveira, J. T., Yin, Y., Li, Y., et al. (2012). Full-length axon regeneration in the adult mouse optic nerve and partial recovery of simple visual behaviors. Proc. Natl. Acad. Sci. U.S.A. 109, 9149-9154. doi: 10.1073/pnas.1119449109

Dickendesher, T. L., Baldwin, K. T., Mironova, Y. A., Koriyama, Y., Raiker, S. J., Askew, K. L., et al. (2012). NgR1 and NgR3 are receptors for chondroitin sulfate proteoglycans. Nat. Neurosci. 15, 703-712. doi: 10.1038/nn.3070

Diem, R., Meyer, R., Weishaupt, J. H., and Bahr, M. (2001). Reduction of potassium currents and phosphatidylinositol 3-kinase-dependent AKT phosphorylation by tumor necrosis factor-(alpha) rescues axotomized retinal ganglion cells from retrograde cell death in vivo. J. Neurosci. 21, 2058-2066.

Donahue, R. J., Maes, M. E., Grosser, J. A., and Nickells, R. W. (2020). BAX-depleted retinal ganglion cells survive and become quiescent following optic nerve damage. Mol. Neurobiol. 57, 1070-1084. doi: 10.1007/s12035-01901783-7

Doyon, N., Prescott, S. A., and De Koninck, Y. (2015). Mild KCC2 hypofunction causes inconspicuous chloride dysregulation that degrades neural coding. Front. Cell. Neurosci. 9:516. doi: 10.3389/fncel.2015.00516

Doyon, N., Vinay, L., Prescott, S. A., and De Koninck, Y. (2016). Chloride regulation: a dynamic equilibrium crucial for synaptic inhibition. Neuron 89, 1157-1172. doi: 10.1016/j.neuron.2016.02.030

Duan, X., Qiao, M., Bei, F., Kim, I. J., He, Z., and Sanes, J. R. (2015). Subtypespecific regeneration of retinal ganglion cells following axotomy: effects of osteopontin and mTOR signaling. Neuron 85, 1244-1256. doi: 10.1016/j. neuron.2015.02.017

Feldheim, D. A., and O'Leary, D. D. (2010). Visual map development: bidirectional signaling, bifunctional guidance molecules, and competition. Cold Spring Harb. Perspect. Biol. 2:a001768. doi: 10.1101/cshperspect.a001768

Fernandes, K. A., Harder, J. M., Fornarola, L. B., Freeman, R. S., Clark, A. F., Pang, I. H., et al. (2012). JNK2 and JNK3 are major regulators of axonal injuryinduced retinal ganglion cell death. Neurobiol. Dis. 46, 393-401. doi: 10.1016/j. nbd.2012.02.003 
Fischer, D., He, Z., and Benowitz, L. I. (2004a). Counteracting the Nogo receptor enhances optic nerve regeneration if retinal ganglion cells are in an active growth state. J. Neurosci. 24, 1646-1651. doi: 10.1523/jneurosci.5119-03.2004

Fischer, D., Petkova, V., Thanos, S., and Benowitz, L. I. (2004b). Switching mature retinal ganglion cells to a robust growth state in vivo: gene expression and synergy with RhoA inactivation. J. Neurosci. 24, 8726-8740. doi: 10.1523/ jneurosci.2774-04.2004

Fordyce, C. B., Jagasia, R., Zhu, X., and Schlichter, L. C. (2005). Microglia Kv1.3 channels contribute to their ability to kill neurons. J. Neurosci. 25, 7139-7149. doi: 10.1523/jneurosci.1251-05.2005

Galvao, J., Iwao, K., Apara, A., Wang, Y., Ashouri, M., Shah, T. N., et al. (2018). The Krüppel-like factor gene target Dusp14 regulates axon growth and regeneration. Invest. Ophthalmol. Vis. Sci. 59, 2736-2747. doi: 10.1167/iovs.17-23319

Gaub, P., Joshi, Y., Wuttke, A., Naumann, U., Schnichels, S., Heiduschka, P., et al. (2011). The histone acetyltransferase p300 promotes intrinsic axonal regeneration. Brain 134(Pt 7), 2134-2148. doi: 10.1093/brain/awr142

Gerdts, J., Summers, D. W., Milbrandt, J., and DiAntonio, A. (2016). Axon self-destruction: new links among SARM1, MAPKs, and NAD+ metabolism. Neuron 89, 449-460. doi: 10.1016/j.neuron.2015.12.023

Goldberg, J. L. (2004). Intrinsic neuronal regulation of axon and dendrite growth. Curr. Opin. Neurobiol. 14, 551-557. doi: 10.1016/j.conb.2004.08.012

Goldberg, J. L. (2012). Role of electrical activity in promoting neural repair. Neurosci. Lett. 519, 134-137. doi: 10.1016/j.neulet.2012.02.003

Goldberg, J. L., and Barres, B. A. (2000). The relationship between neuronal survival and regeneration. Annu. Rev. Neurosci. 23, 579-612. doi: 10.1146/ annurev.neuro.23.1.579

Goldberg, J. L., Espinosa, J. S., Xu, Y., Davidson, N., Kovacs, G. T., and Barres, B. A. (2002a). Retinal ganglion cells do not extend axons by default: promotion by neurotrophic signaling and electrical activity. Neuron 33, 689-702. doi: 10 . 1016/s0896-6273(02)00602-5

Goldberg, J. L., Klassen, M. P., Hua, Y., and Barres, B. A. (2002b). Amacrinesignaled loss of intrinsic axon growth ability by retinal ganglion cells. Science 296, 1860-1864. doi: 10.1126/science.1068428

Grewer, C., Gameiro, A., Zhang, Z., Tao, Z., Braams, S., and Rauen, T. (2008). Glutamate forward and reverse transport: from molecular mechanism to transporter-mediated release after ischemia. IUBMB Life 60, 609-619. doi: 10. 1002/iub.98

Guemez-Gamboa, A., Coufal, N. G., and Gleeson, J. G. (2014). Primary cilia in the developing and mature brain. Neuron 82, 511-521. doi: 10.1016/j.neuron.2014. 04.024

Hanovice, N. J., Li, Y., Danbolt, N. C., Benowitz, L. I., and Rosenberg, P. A. (2019). "Reversal of glutamate transport contributes to retinal zinc elevation and ganglion cell death after optic nerve injury. Program No. 047.14," in Proceedings of the Society for Neuroscience, (Chicago, IL: Neuroscience Meeting Planner).

Hasbargen, T., Ahmed, M. M., Miranpuri, G., Li, L., Kahle, K. T., Resnick, D., et al. (2010). Role of NKCC1 and KCC2 in the development of chronic neuropathic pain following spinal cord injury. Ann. N. Y. Acad. Sci. 1198, 168-172. doi: 10.1111/j.1749-6632.2010.05462.x

He, Z., and Jin, Y. (2016). Intrinsic control of axon regeneration. Neuron 90, 437-451. doi: 10.1016/j.neuron.2016.04.022

Held, A., Major, P., Sahin, A., Reenan, R. A., Lipscombe, D., and Wharton, K. A. (2019). Circuit dysfunction in SOD1-ALS model first detected in sensory feedback prior to motor neuron degeneration is alleviated by BMP signaling. J. Neurosci. 39, 2347-2364. doi: 10.1523/jneurosci.1771-18.2019

Hershfinkel, M. (2018). The zinc sensing receptor, ZnR/GPR39, in health and disease. Int. J. Mol. Sci. 19:439. doi: 10.3390/ijms19020439

Hershfinkel, M., Kandler, K., Knoch, M. E., Dagan-Rabin, M., Aras, M. A., Abramovitch-Dahan, C., et al. (2009). Intracellular zinc inhibits KCC2 transporter activity. Nat. Neurosci. 12, 725-727. doi: 10.1038/nn.2316

Hidalgo, J., Aschner, M., Zatta, P., and Vasak, M. (2001). Roles of the metallothionein family of proteins in the central nervous system. Brain Res. Bull. 55, 133-145. doi: 10.1016/s0361-9230(01)00452-x

Hoffpauir, B., McMains, E., and Gleason, E. (2006). Nitric oxide transiently converts synaptic inhibition to excitation in retinal amacrine cells. J. Neurophysiol. 95, 2866-2877. doi: 10.1152/jn.01317.2005
Hughes, F. M. Jr., and Cidlowski, J. A. (1999). Potassium is a critical regulator of apoptotic enzymes in vitro and in vivo. Adv. Enzyme Regul. 39, 157-171. doi: 10.1016/s0065-2571(98)00010-7

Jackson, K. A., Valentine, R. A., Coneyworth, L. J., Mathers, J. C., and Ford, D. (2008). Mechanisms of mammalian zinc-regulated gene expression. Biochem. Soc. Trans. 36(Pt 6), 1262-1266. doi: 10.1042/bst0361262

Jang, Y., Wang, H., Xi, J., Mueller, R. A., Norfleet, E. A., and Xu, Z. (2007). NO mobilizes intracellular Zn2+ via cGMP/PKG signaling pathway and prevents mitochondrial oxidant damage in cardiomyocytes. Cardiovasc. Res. 75, 426433. doi: 10.1016/j.cardiores.2007.05.015

Janssen, K. T., Mac Nair, C. E., Dietz, J. A., Schlamp, C. L., and Nickells, R. W. (2013). Nuclear atrophy of retinal ganglion cells precedes the bax-dependent stage of apoptosis. Invest. Ophthalmol. Vis. Sci. 54, 1805-1815. doi: 10.1167/iovs. 11-9310

Ji, S. G., Medvedeva, Y. V., and Weiss, J. H. (2020). Zn(2+) entry through the mitochondrial calcium uniporter is a critical contributor to mitochondrial dysfunction and neurodegeneration. Exp. Neurol. 325:113161. doi: 10.1016/j. expneurol.2019.113161

Jiang, D., Sullivan, P. G., Sensi, S. L., Steward, O., and Weiss, J. H. (2001). Zn(2+) induces permeability transition pore opening and release of pro-apoptotic peptides from neuronal mitochondria. J. Biol. Chem. 276, 47524-47529. doi: 10.1074/jbc.M108834200

Kahle, K. T., and Delpire, E. (2016). Kinase-KCC2 coupling: Cl- rheostasis, disease susceptibility, therapeutic target. J. Neurophysiol. 115, 8-18. doi: 10.1152/jn. 00865.2015

Kaila, K., Price, T. J., Payne, J. A., Puskarjov, M., and Voipio, J. (2014). Cationchloride cotransporters in neuronal development, plasticity and disease. Nat. Rev. Neurosci. 15, 637-654. doi: 10.1038/nrn3819

Kaneda, M., Ishii, K., Akagi, T., Tatsukawa, T., and Hashikawa, T. (2005). Endogenous zinc can be a modulator of glycinergic signaling pathway in the rat retina. J. Mol. Histol. 36, 179-185. doi: 10.1007/s10735-005-1693-4

Kardos, J., Kovács, I., Hajós, F., Kálmán, M., and Simonyi, M. (1989). Nerve endings from rat brain tissue release copper upon depolarization. A possible role in regulating neuronal excitability. Neurosci. Lett. 103, 139-144. doi: 10. 1016/0304-3940(89)90565-x

Katome, T., Namekata, K., Guo, X., Semba, K., Kittaka, D., Kawamura, K., et al. (2013). Inhibition of ASK1-p38 pathway prevents neural cell death following optic nerve injury. Cell Death Differ. 20, 270-280. doi: 10.1038/cdd.2012.122

Kikuchi, M., Tenneti, L., and Lipton, S. A. (2000). Role of p38 mitogen-activated protein kinase in axotomy-induced apoptosis of rat retinal ganglion cells. J. Neurosci. 20, 5037-5044.

Kim, T., Soto, F., and Kerschensteiner, D. (2015). An excitatory amacrine cell detects object motion and provides feature-selective input to ganglion cells in the mouse retina. Elife 4:e08025. doi: 10.7554/eLife.08025

Kimura, T., and Kambe, T. (2016). The functions of metallothionein and ZIP and $\mathrm{ZnT}$ transporters: an overview and perspective. Int. J. Mol. Sci. 17:336. doi: 10.3390/ijms17030336

Kleber, A. G. (1984). Extracellular potassium accumulation in acute myocardial ischemia. J. Mol. Cell. Cardiol. 16, 389-394. doi: 10.1016/s0022-2828(84) 80610-0

Knoferle, J., Koch, J. C., Ostendorf, T., Michel, U., Planchamp, V., Vutova, P., et al. (2010). Mechanisms of acute axonal degeneration in the optic nerve in vivo. Proc. Natl. Acad. Sci. U.S.A. 107, 6064-6069. doi: 10.1073/pnas.0909794107

Kochanczyk, T., Drozd, A., and Krezel, A. (2015). Relationship between the architecture of zinc coordination and zinc binding affinity in proteins-insights into zinc regulation. Metallomics 7, 244-257. doi: 10.1039/c4mt00094c

Kolb, H., and Famiglietti, E. V. (1974). Rod and cone pathways in the inner plexiform layer of cat retina. Science 186, 47-49. doi: 10.1126/science.186. 4158.47

Komatsu, M., Wang, Q. J., Holstein, G. R., Friedrich, V. L. Jr., Iwata, J., Kominami, E., et al. (2007). Essential role for autophagy protein Atg7 in the maintenance of axonal homeostasis and the prevention of axonal degeneration. Proc. Natl. Acad. Sci. U.S.A. 104, 14489-14494. doi: 10.1073/pnas.0701311104

Krężel, A., and Maret, W. (2017). The functions of metamorphic metallothioneins in zinc and copper metabolism. Int. J. Mol. Sci. 18:1237. doi: 10.3390/ ijms 18061237 
Krishnan, V., and Gleason, E. (2015). Nitric oxide releases Cl(-) from acidic organelles in retinal amacrine cells. Front. Cell. Neurosci. 9:213. doi: 10.3389/ fncel.2015.00213

Krishnan, V., Maddox, J. W., Rodriguez, T., and Gleason, E. (2017). A role for the cystic fibrosis transmembrane conductance regulator in the nitric oxide-dependent release of $\mathrm{Cl}(-)$ from acidic organelles in amacrine cells. J. Neurophysiol. 118, 2842-2852. doi: 10.1152/jn.00511.2017

Kurimoto, T., Yin, Y., Omura, K., Gilbert, H. Y., Kim, D., Cen, L. P., et al. (2010). Long-distance axon regeneration in the mature optic nerve: contributions of oncomodulin, cAMP, and pten gene deletion. J. Neurosci. 30, 15654-15663. doi: 10.1523/jneurosci.4340-10.2010

Li, S., Yang, C., Zhang, L., Gao, X., Wang, X., Liu, W., et al. (2016). Promoting axon regeneration in the adult CNS by modulation of the melanopsin/GPCR signaling. Proc. Natl. Acad. Sci. U.S.A. 113, 1937-1942. doi: 10.1073/pnas. 1523645113

Li, Y., Andereggen, L., Yuki, K., Omura, K., Yin, Y., Gilbert, H. Y., et al. (2017a). Mobile zinc increases rapidly in the retina after optic nerve injury and regulates ganglion cell survival and optic nerve regeneration. Proc. Natl. Acad. Sci. U.S.A. 114, E209-E218. doi: 10.1073/pnas.1616811114

Li, Y., Wang, F., Chen, X., Wang, J., Zhao, Y., Li, Y., et al. (2019). Zinc-dependent deacetylase (HDAC) inhibitors with different zinc binding groups. Curr. Top. Med. Chem. 19, 223-241. doi: 10.2174/1568026619666190122144949

Li, Y., Yuki, K., Omura, K., Gilbert, H. Y., Yin, Y., De Lima, S., et al. (2017b). "Amacrine cells regulate retinal $\mathrm{Zn}^{2+}$ accumulation, ganglion cell survival, and axon regeneration after optic nerve injury via two distinct nitric oxide mechanisms," in Neuroscience Meeting Planner. Washington, DC: Society for Neuroscience.

Lim, J. H., Stafford, B. K., Nguyen, P. L., Lien, B. V., Wang, C., Zukor, K., et al. (2016). Neural activity promotes long-distance, target-specific regeneration of adult retinal axons. Nat. Neurosci. 19, 1073-1084. doi: 10.1038/nn.4340

Liu, R., Wang, J., Liang, S., Zhang, G., and Yang, X. (2019). Role of NKCC1 and KCC2 in epilepsy: from expression to function. Front. Neurol. 10:1407. doi: 10.3389/fneur.2019.01407

Livesey, F. J., and Cepko, C. L. (2001). Vertebrate neural cell-fate determination: lessons from the retina. Nat. Rev. Neurosci. 2, 109-118. doi: 10.1038/35053522

Maddox, J. W., and Gleason, E. (2017). Nitric oxide promotes GABA release by activating a voltage-independent $\mathrm{Ca}(2+)$ influx pathway in retinal amacrine cells. J. Neurophysiol. 117, 1185-1199. doi: 10.1152/jn.00803.2016

Maddox, J. W., Khorsandi, N., and Gleason, E. (2018). TRPC5 is required for the NO-dependent increase in dendritic $\mathrm{Ca}(2+)$ and GABA release from chick retinal amacrine cells. J. Neurophysiol. 119, 262-273. doi: 10.1152/jn.00500. 2017

Marc, R. E., Anderson, J. R., Jones, B. W., Sigulinsky, C. L., and Lauritzen, J. S. (2014). The AII amacrine cell connectome: a dense network hub. Front. Neural Circuits 8:104. doi: 10.3389/fncir.2014.00104

Marc, R. E., and Liu, W. (2000). Fundamental GABAergic amacrine cell circuitries in the retina: nested feedback, concatenated inhibition, and axosomatic synapses. J. Comp. Neurol. 425, 560-582. doi: 10.1002/1096-9861(20001002) 425:4<560::aid-cne7<3.0.co;2-d

Maret, W. (1995). Metallothionein/disulfide interactions, oxidative stress, and the mobilization of cellular zinc. Neurochem. Int. 27, 111-117. doi: 10.1016/01970186(94)00173-r

Maret, W. (2017). Zinc in cellular regulation: the nature and significance of "Zinc Signals". Int. J. Mol. Sci. 18:2285. doi: 10.3390/ijms18112285

Martinez-Losa, M., Tracy, T. E., Ma, K., Verret, L., Clemente-Perez, A., Khan, A. S., et al. (2018). Nav1.1-overexpressing interneuron transplants restore brain rhythms and cognition in a mouse model of Alzheimer's disease. Neuron 98, 75-89.e75. doi: 10.1016/j.neuron.2018.02.029

McAllister, B. B., and Dyck, R. H. (2017). Zinc transporter 3 (ZnT3) and vesicular zinc in central nervous system function. Neurosci. Biobehav. Rev. 80, 329-350. doi: 10.1016/j.neubiorev.2017.06.006

McCall, K. A., Huang, C.-C., and Fierke, C. A. (2000). Function and mechanism of zinc metalloenzymes. J. Nutr. 130, 1437S-1446S. doi: 10.1093/jn/130.5.1437S

McCord, M. C., and Aizenman, E. (2013). Convergent Ca2+ and Zn2+ signaling regulates apoptotic Kv2.1 K+ currents. Proc. Natl. Acad. Sci. U.S.A. 110, 1398813993. doi: 10.1073/pnas.1306238110

McGregor, M. M., and Nelson, A. B. (2019). Circuit mechanisms of Parkinson's disease. Neuron 101, 1042-1056. doi: 10.1016/j.neuron.2019.03.004
McKeon, R. J., Hoke, A., and Silver, J. (1995). Injury-induced proteoglycans inhibit the potential for laminin-mediated axon growth on astrocytic scars. Exp. Neurol. 136, 32-43. doi: 10.1006/exnr.1995.1081

McLaughlin, B., Pal, S., Tran, M. P., Parsons, A. A., Barone, F. C., Erhardt, J. A., et al. (2001). p38 activation is required upstream of potassium current enhancement and caspase cleavage in thiol oxidant-induced neuronal apoptosis. J. Neurosci. 21, 3303-3311. doi: 10.1523/jneurosci.21-10-03303.2001

Meyer-Franke, A., Wilkinson, G. A., Kruttgen, A., Hu, M., Munro, E., Hanson, M. G. Jr., et al. (1998). Depolarization and cAMP elevation rapidly recruit TrkB to the plasma membrane of CNS neurons. Neuron 21, 681-693. doi: 10.1016/s0896-6273(00)80586-3

Moore, D. L., Apara, A., and Goldberg, J. L. (2011). Kruppel-like transcription factors in the nervous system: novel players in neurite outgrowth and axon regeneration. Mol. Cell. Neurosci. 47, 233-243. doi: 10.1016/j.mcn.2011. 05.005

Moore, D. L., Blackmore, M. G., Hu, Y., Kaestner, K. H., Bixby, J. L., Lemmon, V. P., et al. (2009). KLF family members regulate intrinsic axon regeneration ability. Science 326, 298-301. doi: 10.1126/science.1175737

Moore, Y. E., Kelley, M. R., Brandon, N. J., Deeb, T. Z., and Moss, S. J. (2017). Seizing control of KCC2: a new therapeutic target for epilepsy. Trends Neurosci. 40, 555-571. doi: 10.1016/j.tins.2017.06.008

Nabekura, J., Ueno, T., Okabe, A., Furuta, A., Iwaki, T., Shimizu-Okabe, C., et al. (2002). Reduction of KCC2 expression and GABAA receptor-mediated excitation after in vivo axonal injury. J. Neurosci. 22, 4412-4417.

Nakamura, T., Prikhodko, O. A., Pirie, E., Nagar, S., Akhtar, M. W., Oh, C. K., et al. (2015). Aberrant protein S-nitrosylation contributes to the pathophysiology of neurodegenerative diseases. Neurobiol. Dis. 84, 99-108. doi: 10.1016/j.nbd.2015. 03.017

Nakashima, A. S., and Dyck, R. H. (2009). Zinc and cortical plasticity. Brain Res. Rev. 59, 347-373. doi: 10.1016/j.brainresrev.2008.10.003

Nelson, S. B., and Valakh, V. (2015). Excitatory/inhibitory balance and circuit homeostasis in autism spectrum disorders. Neuron 87, 684-698. doi: 10.1016/j. neuron.2015.07.033

Norsworthy, M. W., Bei, F., Kawaguchi, R., Wang, Q., Tran, N. M., Li, Y., et al. (2017). Sox11 expression promotes regeneration of some retinal ganglion cell types but kills others. Neuron 94, 1112-1120.e4. doi: 10.1016/j.neuron.2017.05. 035

Oh, S. J., Kim, I. B., Lee, M. Y., Chun, M. H., and Chung, J. W. (1998). NOS-like immunoreactive neurons express GABA-like immunoreactivity in rabbit and rat retinae. Exp. Brain Res. 120, 109-113. doi: 10.1007/s002210050383

Palmiter, R. D., Cole, T. B., Quaife, C. J., and Findley, S. D. (1996). ZnT-3, a putative transporter of zinc into synaptic vesicles. Proc. Natl. Acad. Sci. U.S.A. 93, 14934-14939. doi: 10.1073/pnas.93.25.14934

Palop, J. J., Chin, J., and Mucke, L. (2006). A network dysfunction perspective on neurodegenerative diseases. Nature 443, 768-773. doi: 10.1038/nature05289

Palop, J. J., and Mucke, L. (2016). Network abnormalities and interneuron dysfunction in Alzheimer disease. Nat. Rev. Neurosci. 17, 777-792. doi: 10.1038/ nrn.2016.141

Pan, E., Zhang, X. A., Huang, Z., Krezel, A., Zhao, M., Tinberg, C. E., et al. (2011). Vesicular zinc promotes presynaptic and inhibits postsynaptic longterm potentiation of mossy fiber-CA3 synapse. Neuron 71, 1116-1126. doi: 10.1016/j.neuron.2011.07.019

Park, K. K., Liu, K., Hu, Y., Smith, P. D., Wang, C., Cai, B., et al. (2008). Promoting axon regeneration in the adult CNS by modulation of the PTEN/mTOR pathway. Science 322, 963-966. doi: 10.1126/science.1161566

Patel, A. K., Broyer, R. M., Lee, C. D., Lu, T., Louie, M. J., La Torre, A., et al. (2020). Inhibition of GCK-IV kinases dissociates cell death and axon regeneration in CNS neurons. Proc. Natl. Acad. Sci. U.S.A. 117, 33597-33607. doi: 10.1073/pnas. 2004683117

Patrizi, A., Awad, P. N., Chattopadhyaya, B., Li, C., Di Cristo, G., and Fagiolini, M. (2020). Accelerated hyper-maturation of parvalbumin circuits in the absence of MeCP2. Cereb. Cortex 30, 256-268. doi: 10.1093/cercor/bhz085

Payne, J. A., Rivera, C., Voipio, J., and Kaila, K. (2003). Cation-chloride cotransporters in neuronal communication, development and trauma. Trends Neurosci. 26, 199-206. doi: 10.1016/s0166-2236(03)00068-7

Pelzel, H. R., Schlamp, C. L., and Nickells, R. W. (2010). Histone H4 deacetylation plays a critical role in early gene silencing during neuronal apoptosis. BMC Neurosci. 11:62. doi: 10.1186/1471-2202-11-62 
Pfeiffenberger, C., Cutforth, T., Woods, G., Yamada, J., Rentería, R. C., Copenhagen, D. R., et al. (2005). Ephrin-As and neural activity are required for eye-specific patterning during retinogeniculate mapping. Nat. Neurosci. 8 , 1022-1027. doi: 10.1038/nn1508

Pluth, M. D., Chan, M. R., McQuade, L. E., and Lippard, S. J. (2011). Seminaphthofluorescein-based fluorescent probes for imaging nitric oxide in live cells. Inorg. Chem. 50, 9385-9392. doi: 10.1021/ic200986v

Ribas, V. T., Koch, J. C., Michel, U., Bahr, M., and Lingor, P. (2017). Attenuation of axonal degeneration by calcium channel inhibitors improves retinal ganglion cell survival and regeneration after optic nerve crush. Mol. Neurobiol. 54, 72-86. doi: 10.1007/s12035-015-9676-2

Rimmele, T. S., Rocher, A. B., Wellbourne-Wood, J., and Chatton, J. Y. (2017). Control of glutamate transport by extracellular potassium: basis for a negative feedback on synaptic transmission. Cereb. Cortex 27, 3272-3283. doi: 10.1093/ cercor/bhx078

Saadi, R. A., He, K., Hartnett, K. A., Kandler, K., Hershfinkel, M., and Aizenman, E. (2012). SNARE-dependent upregulation of potassium chloride co-transporter 2 activity after metabotropic zinc receptor activation in rat cortical neurons in vitro. Neuroscience 210, 38-46. doi: 10.1016/j.neuroscience.2012.03.001

Sakagami, K., Chen, B., Nusinowitz, S., Wu, H., and Yang, X. J. (2012). PTEN regulates retinal interneuron morphogenesis and synaptic layer formation. Mol. Cell. Neurosci. 49, 171-183. doi: 10.1016/j.mcn.2011.11.007

Saydam, N., Adams, T. K., Steiner, F., Schaffner, W., and Freedman, J. H. (2002). Regulation of metallothionein transcription by the metal-responsive transcription factor MTF-1: identification of signal transduction cascades that control metal-inducible transcription. J. Biol. Chem. 277, 20438-20445. doi: 10.1074/jbc.M110631200

Schmitt, H. M., Pelzel, H. R., Schlamp, C. L., and Nickells, R. W. (2014). Histone deacetylase 3 (HDAC3) plays an important role in retinal ganglion cell death after acute optic nerve injury. Mol. Neurodegener. 9:39. doi: 10.1186/1750-13269-39

Sekler, I., Sensi, S. L., Hershfinkel, M., and Silverman, W. F. (2007). Mechanism and regulation of cellular zinc transport. Mol. Med. 13, 337-343. doi: 10.2119/200700037.Sekler

Sensi, S. L., Paoletti, P., Bush, A. I., and Sekler, I. (2009). Zinc in the physiology and pathology of the CNS. Nat. Rev. Neurosci. 10, 780-791. doi: 10.1038/nrn2734

Sensi, S. L., Paoletti, P., Koh, J. Y., Aizenman, E., Bush, A. I., and Hershfinkel, M. (2011). The neurophysiology and pathology of brain zinc. J. Neurosci. 31, 16076-16085. doi: 10.1523/jneurosci.3454-11.2011

Sensi, S. L., Yin, H. Z., Carriedo, S. G., Rao, S. S., and Weiss, J. H. (1999). Preferential Zn2+ influx through Ca2+-permeable AMPA/kainate channels triggers prolonged mitochondrial superoxide production. Proc. Natl. Acad. Sci. U.S.A. 96, 2414-2419. doi: 10.1073/pnas.96.5.2414

Sergeeva, E. G., Li, Y., Benowitz, L. I., and Rosenberg, P. A. (2019). "Inhibition of synaptic zinc release by tetanus neurotoxin promotes retinal ganglion cell survival and axon regeneration following optic nerve injury. Program No. 047.09," in Proceedings of the Society for Neuroscience, (Chicago, IL: Neuroscience Meeting Planner).

Simon, C. M., Janas, A. M., Lotti, F., Tapia, J. C., Pellizzoni, L., and Mentis, G. Z. (2016). A stem cell model of the motor circuit uncouples motor neuron death from hyperexcitability induced by SMN deficiency. Cell Rep. 16, 1416-1430. doi: 10.1016/j.celrep.2016.06.087

Smith, P. D., Sun, F., Park, K. K., Cai, B., Wang, C., Kuwako, K., et al. (2009). SOCS3 deletion promotes optic nerve regeneration in vivo. Neuron 64, 617-623. doi: 10.1016/j.neuron.2009.11.021

So, K. F., and Aguayo, A. J. (1985). Lengthy regrowth of cut axons from ganglion cells after peripheral nerve transplantation into the retina of adult rats. Brain Res. 328, 349-354. doi: 10.1016/0006-8993(85)91047-9

Spahl, D. U., Berendji-Grun, D., Suschek, C. V., Kolb-Bachofen, V., and Kroncke, K. D. (2003). Regulation of zinc homeostasis by inducible NO synthase-derived NO: nuclear metallothionein translocation and intranuclear $\mathrm{Zn} 2+$ release. Proc. Natl. Acad. Sci. U.S.A. 100, 13952-13957. doi: 10.1073/pnas.2335190100

Sun, F., Park, K. K., Belin, S., Wang, D., Lu, T., Chen, G., et al. (2011). Sustained axon regeneration induced by co-deletion of PTEN and SOCS3. Nature 480, 372-375. doi: 10.1038/nature10594

Suwa, H., Saint-Amant, L., Triller, A., Drapeau, P., and Legendre, P. (2001). Highaffinity zinc potentiation of inhibitory postsynaptic glycinergic currents in the zebrafish hindbrain. J. Neurophysiol. 85, 912-925. doi: 10.1152/jn.2001.85.2.912
Szatkowski, M., Barbour, B., and Attwell, D. (1990). Non-vesicular release of glutamate from glial cells by reversed electrogenic glutamate uptake. Nature 348, 443-446. doi: 10.1038/348443a0

Tang, X., Drotar, J., Li, K., Clairmont, C. D., Brumm, A. S., Sullins, A. J., et al. (2019). Pharmacological enhancement of KCC2 gene expression exerts therapeutic effects on human Rett syndrome neurons and Mecp2 mutant mice. Sci. Transl. Med. 11:eaau0164. doi: 10.1126/scitranslmed.aau0164

Tang, X., Kim, J., Zhou, L., Wengert, E., Zhang, L., Wu, Z., et al. (2016). KCC2 rescues functional deficits in human neurons derived from patients with Rett syndrome. Proc. Natl. Acad. Sci. U.S.A. 113, 751-756. doi: 10.1073/pnas. 1524013113

Trakhtenberg, E. F., Li, Y., Feng, Q., Tso, J., Rosenberg, P. A., Goldberg, J. L., et al. (2018). Zinc chelation and Klf9 knockdown cooperatively promote axon regeneration after optic nerve injury. Exp. Neurol. 300, 22-29. doi: 10.1016/j. expneurol.2017.10.025

Tran, N. M., Shekhar, K., Whitney, I. E., Jacobi, A., Benhar, I., Hong, G., et al. (2019). Single-cell profiles of retinal ganglion cells differing in resilience to injury reveal neuroprotective genes. Neuron 104, 1039-1055.e12. doi: 10.1016/ j.neuron.2019.11.006

Varadarajan, S. G., and Huberman, A. D. (2018). Assembly and repair of eyeto-brain connections. Curr. Opin. Neurobiol. 53, 198-209. doi: 10.1016/j.conb. 2018.10.001

Vardi, N., Zhang, L. L., Payne, J. A., and Sterling, P. (2000). Evidence that different cation chloride cotransporters in retinal neurons allow opposite responses to GABA. J. Neurosci. 20, 7657-7663.

Vargas, M. E., Yamagishi, Y., Tessier-Lavigne, M., and Sagasti, A. (2015). Live imaging of calcium dynamics during axon degeneration reveals two functionally distinct phases of calcium influx. J. Neurosci. 35, 15026-15038. doi: 10.1523/jneurosci.2484-15.2015

Vergnano, A. M., Rebola, N., Savtchenko, L. P., Pinheiro, P. S., Casado, M., Kieffer, B. L., et al. (2014). Zinc dynamics and action at excitatory synapses. Neuron 82 , 1101-1114. doi: 10.1016/j.neuron.2014.04.034

Vidal-Sanz, M., Bray, G. M., Villegas-Perez, M. P., Thanos, S., and Aguayo, A. J. (1987). Axonal regeneration and synapse formation in the superior colliculus by retinal ganglion cells in the adult rat. J. Neurosci. 7, 2894-2909.

Vu, T. Q., Payne, J. A., and Copenhagen, D. R. (2000). Localization and developmental expression patterns of the neuronal K-Cl cotransporter (KCC2) in the rat retina. J. Neurosci. 20, 1414-1423.

Wainger, B. J., Kiskinis, E., Mellin, C., Wiskow, O., Han, S. S., Sandoe, J., et al. (2014). Intrinsic membrane hyperexcitability of amyotrophic lateral sclerosis patient-derived motor neurons. Cell Rep. 7, 1-11. doi: 10.1016/j.celrep.2014.03. 019

Wake, H., Watanabe, M., Moorhouse, A. J., Kanematsu, T., Horibe, S., Matsukawa, N., et al. (2007). Early changes in KCC2 phosphorylation in response to neuronal stress result in functional downregulation. J. Neurosci. 27, 1642-1650. doi: 10.1523/jneurosci.3104-06.2007

Wang, H., Li, J., Follett, P. L., Zhang, Y., Cotanche, D. A., Jensen, F. E., et al. (2004). 12-Lipoxygenase plays a key role in cell death caused by glutathione depletion and arachidonic acid in rat oligodendrocytes. Eur. J. Neurosci. 20, 2049-2058. doi: 10.1111/j.1460-9568.2004.03650.x

Wang, X., Hasan, O., Arzeno, A., Benowitz, L. I., Cafferty, W. B., and Strittmatter, S. M. (2012). Axonal regeneration induced by blockade of glial inhibitors coupled with activation of intrinsic neuronal growth pathways. Exp. Neurol. 237, 55-69. doi: 10.1016/j.expneurol.2012.06.009

Wang, X. W., Li, Q., Liu, C. M., Hall, P. A., Jiang, J. J., Katchis, C. D., et al. (2018). Lin28 signaling supports mammalian PNS and CNS axon regeneration. Cell Rep. 24, 2540-2552.e6. doi: 10.1016/j.celrep.2018.07.105

Watanabe, M., and Fukuda, A. (2015). Development and regulation of chloride homeostasis in the central nervous system. Front. Cell. Neurosci. 9:371. doi: 10.3389/fncel.2015.00371

Watkins, T. A., Wang, B., Huntwork-Rodriguez, S., Yang, J., Jiang, Z., EasthamAnderson, J., et al. (2013). DLK initiates a transcriptional program that couples apoptotic and regenerative responses to axonal injury. Proc. Natl. Acad. Sci. U.S.A. 110, 4039-4044. doi: 10.1073/pnas.1211074110

Welsbie, D. S., Yang, Z., Ge, Y., Mitchell, K. L., Zhou, X., Martin, S. E., et al. (2013). Functional genomic screening identifies dual leucine zipper kinase as a key mediator of retinal ganglion cell death. Proc. Natl. Acad. Sci. U.S.A. 110, 4045-4050. doi: 10.1073/pnas.1211284110 
Wolhuter, K., Whitwell, H. J., Switzer, C. H., Burgoyne, J. R., Timms, J. F., and Eaton, P. (2018). Evidence against stable protein S-nitrosylation as a widespread mechanism of post-translational regulation. Mol. Cell 69, 438-450.e5. doi: 10. 1016/j.molcel.2017.12.019

Xie, L., Yin, Y., Gilbert, H. Y., and Benowitz, L. I. (2021). Chemokine CCL5 induces extensive optic nerve regeneration and mediates many of the effects of CNTF gene therapy. Proc. Natl. Acad. Sci. U.S.A. 118:e2017282118.

Yamamoto, R., Bredt, D. S., Snyder, S. H., and Stone, R. A. (1993). The localization of nitric oxide synthase in the rat eye and related cranial ganglia. Neuroscience 54, 189-200. doi: 10.1016/0306-4522(93)90393-t

Yang, J., Wu, Z., Renier, N., Simon, D. J., Uryu, K., Park, D. S., et al. (2015). Pathological axonal death through a MAPK cascade that triggers a local energy deficit. Cell 160, 161-176. doi: 10.1016/j.cell.2014.11.053

Yap, E. L., and Greenberg, M. E. (2018). Activity-regulated transcription: bridging the gap between neural activity and behavior. Neuron 100, 330-348. doi: 10 . 1016/j.neuron.2018.10.013

Yassin, L., Radtke-Schuller, S., Asraf, H., Grothe, B., Hershfinkel, M., Forsythe, I. D., et al. (2014). Nitric oxide signaling modulates synaptic inhibition in the superior paraolivary nucleus (SPN) via cGMP-dependent suppression of KCC2. Front. Neural Circuits 8:65. doi: 10.3389/fncir.2014.00065

Yin, Y., De Lima, S., Gilbert, H. Y., Hanovice, N. J., Peterson, S. L., Sand, R. M., et al. (2019). Optic nerve regeneration: a long view. Restor. Neurol. Neurosci. 37, 525-544. doi: 10.3233/rnn- 190960

Yin, Y., Xie, L., Gilbert, H. Y., Berlinicke, C., Cen, L. P., Li, Y., et al. (2018). “SDF1 is highly expressed in macrophages and contributes to inflammation-induced optic nerve regeneration. Program No. 115.18," in Proceedings of the Society for Neuroscience, (San Diego, CA: Neuroscience Meeting Planner).

Yu, S. P., Yeh, C. H., Sensi, S. L., Gwag, B. J., Canzoniero, L. M., Farhangrazi, Z. S., et al. (1997). Mediation of neuronal apoptosis by enhancement of outward potassium current. Science 278, 114-117. doi: 10.1126/science.278.5335.114

Zhai, Q., Wang, J., Kim, A., Liu, Q., Watts, R., Hoopfer, E., et al. (2003). Involvement of the ubiquitin-proteasome system in the early stages of wallerian degeneration. Neuron 39, 217-225. doi: 10.1016/s0896-6273(03)00429-x

Zhang, Y., Aizenman, E., DeFranco, D. B., and Rosenberg, P. A. (2007). Intracellular zinc release, 12-lipoxygenase activation and MAPK dependent neuronal and oligodendroglial death. Mol. Med. 13, 350-355. doi: 10.2119/ 2007-00042.Zhang

Zhang, Y., and Rosenberg, P. A. (2004). Caspase-1 and poly (ADP-ribose) polymerase inhibitors may protect against peroxynitrite-induced neurotoxicity independent of their enzyme inhibitor activity. Eur. J. Neurosci. 20, 1727-1736. doi: 10.1111/j.1460-9568.2004.03651.x

Zhang, Y., Wang, H., Li, J., Dong, L., Xu, P., Chen, W., et al. (2006). Intracellular zinc release and ERK phosphorylation are required upstream of 12 lipoxygenase activation in peroxynitrite toxicity to mature rat oligodendrocytes. J. Biol. Chem. 281, 9460-9470. doi: 10.1074/jbc.M510650200

Zhang, Y., Wang, H., Li, J., Jimenez, D. A., Levitan, E. S., Aizenman, E., et al. (2004). Peroxynitrite-induced neuronal apoptosis is mediated by intracellular zinc release and 12-lipoxygenase activation. J. Neurosci. 24, 10616-10627. doi: 10.1523/jneurosci.2469-04.2004

Zhang, Y., Williams, P. R., Jacobi, A., Wang, C., Goel, A., Hirano, A. A., et al. (2019). Elevating growth factor responsiveness and axon regeneration by modulating presynaptic inputs. Neuron 103, 39-51.e5. doi: 10.1016/j.neuron.2019. 04.033

Zhang, Z. Z., Gong, Y. Y., Shi, Y. H., Zhang, W., Qin, X. H., and Wu, X. W. (2012). Valproate promotes survival of retinal ganglion cells in a rat model of optic nerve crush. Neuroscience 224, 282-293. doi: 10.1016/j.neuroscience.2012. 07.056

Zhong, Y. S., Wang, J., Liu, W. M., and Zhu, Y. H. (2013). Potassium ion channels in retinal ganglion cells (review). Mol. Med. Rep. 8, 311-319. doi: 10.3892/mmr. 2013.1508

Zott, B., Busche, M. A., Sperling, R. A., and Konnerth, A. (2018). What happens with the circuit in Alzheimer's disease in mice and humans? Annu. Rev. Neurosci. 41, 277-297. doi: 10.1146/annurev-neuro-080317-061725

Zott, B., Simon, M. M., Hong, W., Unger, F., Chen-Engerer, H. J., Frosch, M. P., et al. (2019). A vicious cycle of beta amyloid-dependent neuronal hyperactivation. Science 365, 559-565. doi: 10.1126/science. aay0198

Conflict of Interest: The authors declare that the research was conducted in the absence of any commercial or financial relationships that could be construed as a potential conflict of interest.

Copyright (C) 2021 Sergeeva, Rosenberg and Benowitz. This is an open-access article distributed under the terms of the Creative Commons Attribution License (CC BY). The use, distribution or reproduction in other forums is permitted, provided the original author(s) and the copyright owner(s) are credited and that the original publication in this journal is cited, in accordance with accepted academic practice. No use, distribution or reproduction is permitted which does not comply with these terms. 